University of Nebraska - Lincoln

DigitalCommons@University of Nebraska - Lincoln

Faculty Publications from the Harold W. Manter Laboratory of Parasitology

4-2006

\title{
Systematics and Emerging Infectious Diseases: From Management to Solution
}

\author{
Daniel R. Brooks \\ University of Toronto,dnlbrooks@gmail.com \\ Eric P. Hoberg \\ United States Department of Agriculture, Agricultural Research Service, geocolonizer@gmail.com
}

Follow this and additional works at: https://digitalcommons.unl.edu/parasitologyfacpubs

Part of the Parasitology Commons

Brooks, Daniel R. and Hoberg, Eric P., "Systematics and Emerging Infectious Diseases: From Management to Solution" (2006). Faculty Publications from the Harold W. Manter Laboratory of Parasitology. 244. https://digitalcommons.unl.edu/parasitologyfacpubs/244

This Article is brought to you for free and open access by the Parasitology, Harold W. Manter Laboratory of at DigitalCommons@University of Nebraska - Lincoln. It has been accepted for inclusion in Faculty Publications from the Harold W. Manter Laboratory of Parasitology by an authorized administrator of DigitalCommons@University of Nebraska - Lincoln. 


\title{
Systematics and Emerging Infectious Diseases: From Management to Solution
}

\author{
Daniel R. Brooks and Eric P. Hoberg*, Department of Zoology, University of Toronto, Toronto, Ontario M5S 3G5 Canada; * U.S. National \\ Parasite Collection \& Animal Parasitic Disease Laboratory, USDA, Agricultural Research Service, BARC East No. 1180,10300 Baltimore \\ Avenue, Beltsville, Maryland 20705. e-mail: dbrooks@zoo.utoronto.ca
}

\begin{abstract}
The crisis of emerging infectious disease stems from the absence of comprehensive taxonomic inventories of the world's parasites, which includes the world's pathogens. Recent technological developments raise hopes that the global inventory of species, including potential pathogens, can be accomplished in a timely and cost-effective manner. The phylogenetics revolution initiated by systematists provides a means by which information about pathogen transmission dynamics can be placed in a predictive framework. Increasingly, that information is widely available in digital form on the internet. Systematic biology is well positioned to play a crucial role in efforts to be proactive in the arena of emerging parasitic and infectious diseases.
\end{abstract}

The biodiversity crisis often is considered solely one of habitat loss and species extinction. It is, however, also a crisis of emerging infectious disease (EID) (Daszak et al., 2000; Harvell et al., 2002; Woolhouse, 2002; Epstein et al., 2003; Brooks and Ferrao, 2005). In popular parlance, the term "emerging infectious disease" means primarily viral, sometimes bacterial, infections of humans that show up unexpectedly. More than $50 \%$ of the known species on this planet are parasites of some form, including all viruses and most bacteria, as well as the eukaryotic species most commonly associated with parasitology. These include agents of diseases affecting not only humans, but also livestock, crops, and wildlife. That is, all pathogens are parasites, but not all parasites are pathogens in all circumstances. Restricting the term "emerging infectious disease" to a subset of species of human health concern gives a misleading, falsely comforting, impression of the scope of the crisis. Thinking that EIDs are likely to be rare, much attention is given to managing an EID once it has emerged, but little attention is paid to its origins, beyond a search for the taxonomic identity of the parasite acting as the pathogen, and its immediate reservoir, if there is one. That is, we usually spend our energies fighting the immediate problem, and neglect looking ahead to trying to mitigate the occurrence of additional EIDs. This is managing a problem, not solving it.

Parasites, including viruses and many prokaryotic microbes, have dual and conflicting significance. On the one hand, they may regulate host populations, playing a central role in maintenance of genetic diversity and structuring of vertebrate and invertebrate communities. On the other hand, they may represent threats to human health, agriculture, natural systems, conservation practices, and the global economy via (1) translocation, introduction, and dissemination; (2) faunal disruption and ecological release; (3) increasing host population density; and (4) amplification of parasite populations linked to environmental change, such as global warming (Hoberg, 1997; Altizer et al., 2003; Horwitz and Wilcox, 2005). Knowledge of the diversity and distribution of known and potential pathogens is critical in limiting economic, societal, and biotic impacts and liability in management of endemic or exotic organisms (Brooks and Hoberg, 2000, 2001; Brooks, 2003). Yet, we find that our knowledge remains insufficient for patterns of diversity, biogeography, and host associations, and, remarkably, even in relatively wellstudied regions, we continue to make substantial discoveries about the distribution of EIDs (Kutz et al., 2004).

Anticipating a problem is always more time- and cost-effective than responding to a crisis, no matter how effective the response. Systematic biology provides and integrates the knowledge that is crucial for any effort to be proactive in the arena of emerging parasitic and infectious diseases. That knowledge is organized into 3 interconnected research programs of local risk assessment, the evolutionary arena of EIDs, and global risk assessment.

\section{LOCAL RISK ASSESSMENT}

Some non-native parasites have become established in the areas where they have been introduced (Torchin et al., 2003). Rapid estab- lishment and spread of introduced pathogens is facilitated by transmission dynamics that are specialized and phylogenetically conservative, and we can use such information to assess the risk of EIDs. For example, the inventory of eukaryotic parasites of vertebrates of the Area de Conservacion Guanacaste (hereafter ACG), a World Heritage Site in northwestern Costa Rica (http://www.parasiterus.com), documents species of special concern. White-tailed deer, Odocoileus virginianus, are infected by 18 species of parasites (Carreno et al., 2001), including 6 species of ticks and the nematodes Parelaphostrongylus tenuis and Ashworthius patriciapillittae. None of the tick species is a known reservoir for Borellia burgdorferi, causative agent of Lyme disease, and no cases of Lyme disease have been reported from Costa Rica. Some of the ticks, however, are relatives of known vectors for Lyme disease, so there is an expectation, derived from historical and systematic data, that this debilitating illness could be introduced to Costa Rica inadvertently by natural range expansion or anthropogenic processes, such as a visit by an asymptomatic eco-tourist.

Native parasites also can be a potential source of EIDs. For example, Parelaphostrongylus tenuis lives in the meninges of ungulates as adult parasites, causing neurological disorders in hosts other than white-tailed deer (Lankester and Fong, 1989; Samuel et al., 1992; Woodford and Rossiter, 1994). Translocation with the introduction of parasites or exposure to novel pathogens is a major consideration in wildlife management decisions (Lankester and Fong, 1989; Samuel et al., 1992; Woodford and Rossiter, 1994; Daszak et al., 2000). Given the potential for neurological disease in susceptible hosts, we now know that care must be taken when considering introduction of, e.g., llamas or alpacas for commercial purposes onto farms on the margins of the ACG, or reintroduction of brocket deer (Mazama americana) within the ACG. Prior to its discovery in Costa Rica, P. tenuis was not known south of Texas, suggesting that it also occurs in all countries between the United States and Costa Rica.

In a complementary manner, Ashworthius patriciapilittae, another parasite inhabiting white-tailed deer in the ACG, closely resembles Haemonchus contortus, an important pathogen of livestock, especially sheep, and definitive identification is necessary for their differentiation. Ashworthius patriciapilitta is a member of a group that radiated in cervids and bovids in the Old World, with subsequent dispersal to the New World (Kennedy, 1993; Scholz and Cappellaro, 1993; Hoberg and Lichtenfels, 1994; Hoberg et al., 1995; Hoberg, 1997; Barse and Secor, 1999; Hoberg et al., 1999; Hoberg, Kocan, and Ricard, 2001; Hoberg et al., 2002). If $A$. patriciapilittae is widespread in temperate latitudes across the Western Hemisphere, some previous reports of $H$. contortus in white-tailed deer and other endemic cervids are likely to be in error. Money and effort expended on controlling $H$. contortus, in part through minimizing contact between livestock and deer, thus has been spent needlessly. Alternatively, if $A$. patriciapilittae currently is restricted to the southernmost range of $O$. virginanus because of cooling of the boreal and temperate regions of the Nearctic, it represents a potential EID of wildlife and livestock that may have a capacity to move north as global warming progresses. In either event, there is reason for concern.

\section{THE EVOLUTIONARY ARENA OF EID}

When ancestral humans moved out of the African forest and onto the savannah during the late Pliocene and early Pleistocene, they made a rapid transition from herbivory to facultative carnivory to active predation. During that time, humans apparently shared more than just food with other apex carnivores, becoming hosts to species of cestodes, e.g., Taenia spp., whose closest relatives inhabit hyenas, large cats, and African hunting dogs (Hoberg et al., 2000, Hoberg, Alkire et al., 2001). This pattern is repeated in 2 other parasite groups, hookworms (Oesophagostomum sp.) and pinworms (Enterobius sp.). Although phylo- 


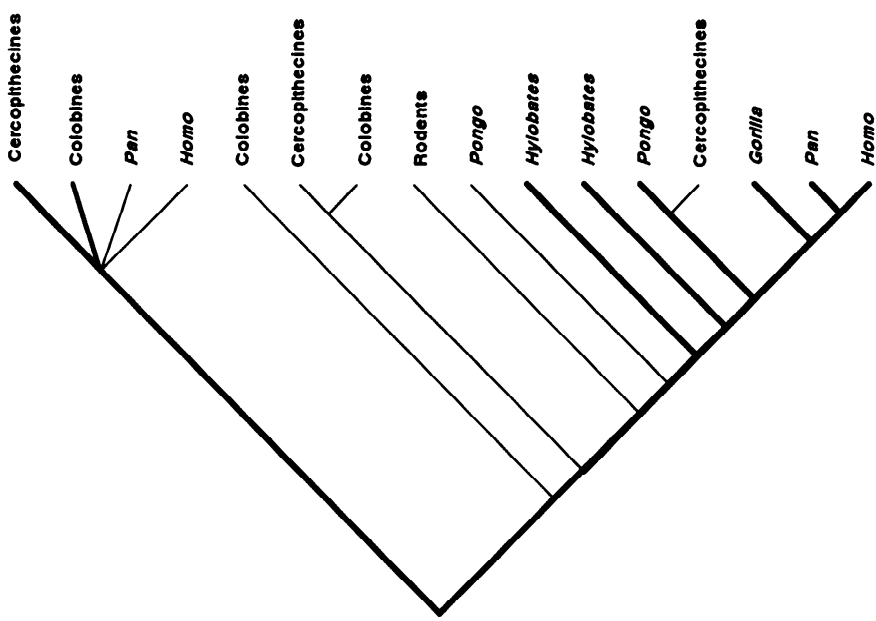

FIGURE 1. Branching diagram indicating host context of parasite speciation events (host cladogram) implied by phylogenies for nematode groups Enterobius sp. and Oesophagostomum sp. (Conoweberia). Heavy lines indicate parasite associations congruent with host phylogeny; thin lines indicate host-switching events, or ancient EIDs. (For methodology, see Wojcicki and Brooks 2004, 2005; Ferrao and Brooks, 2005.)

genetic analysis depicts long-term associations between these parasites and hominoids, one-third of their host associations are the result of host switches (Fig. 1), most of which occurred during episodes of biotic expansion since the Miocene (Fig. 2) (Brooks and Ferrao, 2005).

Systematic studies integrating morphology, molecules, phylogeny, biogeography, coevolution, and ecology, with refined understanding of fossil and recent species, define the evolutionary arena of EIDs. As shown above, movement of hosts and parasites from their areas and ecological contexts of origin into novel areas and ecosystems leads to rapid host switches (through a process known as "ecological fitting"; Janzen, 1985; Brooks and McLennan, 2002; Brooks and Ferrao, in press), some of which may be sufficiently maladapted to produce disease. In the past, episodes of regional to global climate change have catalyzed such episodes, with biotic expansion as a primary mechanism for dissemination of pathogens (Hoberg, 1997). The current episode of EIDs has been catalyzed by anthropogenic activities, but the results are similar. "New" diseases emerge either as a result of geographic spread of parasites and pathogens from their places of origin into novel areas or by the modification to ecosystems in which they originated or were introduced. Thus, an evolutionary context is established for invasive and emergent pathogens on deep historical and broad geographic scales.

\section{GLOBAL RISK ASSESSMENT}

If our knowledge of pathogen diversity is equivalent to our overall knowledge of biodiversity, we have documented fewer than $10 \%$ of the world's pathogens. The remaining $90 \%$ represent the realm of potential EIDs. That realm of the EID crisis comprises the occurrence of susceptible hosts outside the area of origin for each pathogen, intersecting with our fundamental ignorance of their phylogeny, biogeography, host specificity, and transmission dynamics. It is not an overstatement to say that the crisis stems from the absence of comprehensive systematic inventories of the world's parasites and pathogens. It is impossible to be proactive about public health and veterinary, crop, or wildlife diseases caused by species whose existence has not yet been documented. During the past $15 \mathrm{yr}$, systematists have made a concerted effort to determine how we might change from an ignorance-based stance of crisis response to a knowledge-based foundation of preventive action. The most general statements for a transformation in philosophy and for those planning efforts are the 3 main goals of the Global Taxonomy Initiative (GTI) (www.biodiv.org; GTI, 1999).

The first goal is to complete the global inventory of species, an absolute necessity if we are to assess risk and be proactive (Brooks and Hoberg, 2000; GTI, 1999). For example, until recently, techniques for isolating and identifying particular viral and bacterial pathogens were

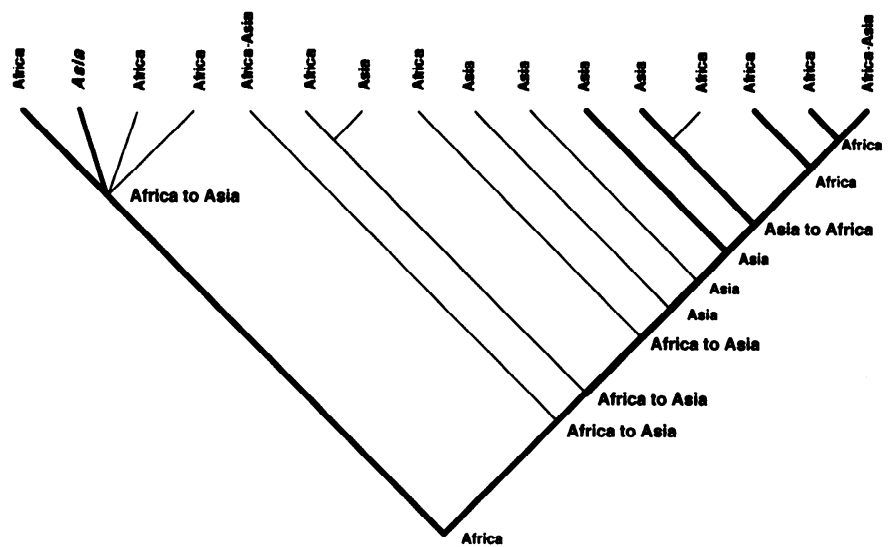

FIGURE 2. Branching diagram indicating geographic context of speciation events (area cladogram) implied by phylogenies for Enterobius sp. and Oeoshagostomum (Conoweberia) sp. Notations at nodes indicate episodes of isolation (in either "Asia" or "Africa") and biotic expansion ("Africa to Asia" or "Asia to Africa"). Thin lines connected to biotic expansion nodes are EIDs associated with host switches during episodes of climate change. (For methodology see Wojcicki and Brooks, 2004, 2005; Ferrao and Brooks, 2005.)

so costly in terms of time and money that inventory efforts required for proactive strategies were impossible. Technological advances in imaging and computer-assisted morphological analysis, coupled with ever cheaper and faster molecular analysis, all performed by ever-faster and cheaper computers make a once daunting task economically feasible.

At the moment, considerable excitement surrounds the proposal to provide rapid species identification using a genetic "bar code" (Hebert et al., 2003). In addition to increasing the rate at which species are documented, the ability to match genetic profiles for different developmental stages of each pathogen species will accelerate enormously the pace at which we document the transmission dynamics of potential EIDs. This renewed interest in the global inventory, although created by a breakthrough in laboratory-based technology, emphasizes the importance of field-based systematists. They are the specialists who know how to find, collect, and presort specimens for the bar coders, while collecting and recording critical natural history information. Their identifications will be the industry standard until a majority of species have been bar coded, and will be essential to calibrating the progress of the bar coding initiative. Additional speed can be realized by undertaking integrated and taxonomically broad-based inventory activities (Janzen, 1993; Janzen and Hallwachs, 1994), in which relatively few field-based specialists are assisted by cadres of parataxonomists (Janzen et al., 1993). For example, 2 inventories in the ACG rely on many of the same parataxonomists to collect specimens of different life cycle stages of lepidopterans, their host plants, and their parasites and parasitoids (http:// janzen.sas.upenn.edu/) and to collect specimens of different life cycle stages of parasites and their vertebrate hosts (http://brooksweb.zoo. utoronto.ca/index.html), for both morphological and molecular analysis.

The second goal of the GTI is to put all of the information collected by biologists into a predictive framework. Phylogenetic classification systems are the most predictive information systems about organisms and their places in the biosphere currently available. The predictable parts of biological systems are the stable elements, form and function, autecological and synecological, that have persisted through evolutionary time. Shared history allows us to make predictions, and this buys us time and saves money, two resources that are in short supply in battling the EID crisis (Brooks and McLennan, 2002). Although contemporary phylogenetic analysis is characterized by diverse methods, all produce highly similar results, and simulation and experimental studies suggest they will converge on the same answer more and more as we obtain more information (Folinsbee et al., in press).

The third goal of the GTI is to get critical information to concerned stakeholders, in this case physicians, veterinarians, researchers, policy makers, and the general public, anywhere in the world. Today, this means putting that information into digital form that is readily available over the Internet. Complementing this goal of the GTI is the Global 
Biodiversity Information Facility (GBIF) (www.gbif.net), whose goal is to provide access for all people to all biodiversity information, from individual web sites to institutional outlets, to comprehensive information projects such as the Encyclopedia of Life (www.pinheadinstitute. org).

\section{CONCLUSIONS}

Those working in the realm of EIDs seldom have felt the need to document biodiversity within an accurate systematic context for parasites, pathogens, vectors, or hosts. Their focus thus often has been biased toward what we already know as invasive or emergent, e.g., a response-based system, rather than what remains to be discovered, e.g., a prediction-based system (Daszak et al., 2000). A contemporary focus has emphasized further "what was left behind" during translocation of hosts (Torchin et al., 2003), in contrast to what components of parasite diversity have established successfully and become emergent, making an unnecessary distinction preventing us from taking advantage of the fact that contemporaneous processes do not differ materially from those embedded in a deeper historical continuum.

If we could be confident that EIDs were a rare phenomenon, perhaps it would be cost-effective to engage in the kind of crisis response we have seen globally to this point in time. Unfortunately, the evolutionary perspective provided by systematists leads us to assume that the potential number of EIDs is very large; there are many "accidents waiting to happen" as a result of continued anthropogenic activities. Our lack of a comprehensive taxonomic inventory of pathogens on this planet, and of phylogenetic assessments of their coevolutionary and biogeographic histories, is a major hindrance to dealing with the problem (Brooks and Hoberg, 2000; Horwitz and Wilcox, 2005). Our past attempts to manage biodiversity have not been very successful (Fayer, 2000), and we believe it is time to shift our attention to problem-solving.

On a positive note, if EIDs are a regular feature of biogeographic dispersal associated with large-scale environmental changes, we can understand the contemporary EID crisis and learn from the lessons of (evolutionary) history. We can hope to move from being ignorant-reactive to being informed-proactive. We thus wholeheartedly concur with Daszak et al. (2004), calling for the formation of multidisciplinary groups of scientists focused on "solution-oriented" approaches, and proposing that experts in the integration of phylogenetic and ecological information be included in those groups.

Society, through its public, wildlife, and livestock health managers, must decide whether to expend its funds continuing to manage the EID crisis or to solve it. We have the tools and the personnel to move from being less uninformed-reactive to more informed-proactive. For this to happen, however, we must forego the usual academic practice of creating exclusive enclaves of research and become more inclusive. How many new EIDs will manifest themselves while we argue about the proper definition of EID? The term Emerging Infectious Disease needs to encompass a much wider range of both hosts and parasites. At the moment, specialists working with eukaryotic parasites have much more experience with basic inventory work, phylogenetic analysis, and integrative evolutionary and ecological studies than those working with viruses and bacteria. We call for an immediate integration of current approaches with a powerful foundation derived from the predictive and historical nature of systematics.

Acknowledgments: Material presented herein was presented as part of the AAAS symposium "Systematics: Vanishing Safety Net for Food Security and the Environment" stemming from the Beltsville Systematics Summit, Beltsville Area Research Center, Agricultural Research Service, USDA, held in November 2002. The authors thank the organizers of the Systematics Summit, P. Johnson and M. Schauff, for inviting them to present these views. DRB acknowledges funding from the Natural Sciences and Engineering Research Council of Canada.

\section{LITERATURE CITED}

Altizer, S., D. Harvell, and E. Friedle. 2003. Rapid evolutionary dynamics and disease threats to biodiversity. Trends In Ecology \& Evolution 18: 589-596.

BARSE, A. M., AND D. H. SECOR. 1999. An exotic nematode parasite of the American eel. Fisheries 24: 6-10.
BROOKs, D. R. 2003. Parasite systematics in a new age of discovery. Journal of Parasitology 89(suppl.): S72-S77.

, AND A. FERRAO. 2005. The historical biogeography of coevolution: emerging infectious diseases are evolutionary accidents waiting to happen. Journal of Biogeography 32: 1291-1299.

, AND E. P. HoBERG. 2000. Triage for the biosphere: The need and rationale for taxonomic inventories and phylogenetic studies of parasites. Comparative Parasitology 68: 1-25.

, AND - 2001. Parasite systematics in the 21 st century: Opportunities and obstacles. Trends in Parasitology 17: 273-275.

, AND D. A. MCLenNan. 2002. The nature of diversity: An evolutionary voyage of discovery. University of Chicago Press, Chicago, Illinois, $668 \mathrm{p}$.

Carreno, R. A., L. A. Durden, D. R. Brooks, A. Abrams, and E. P. HOBERG. 2001. Parelaphostrongylus tenuis and other parasites of white-tailed deer (Odocoileus virginianus) in Costa Rica. Comparative Parasitology 68: 177-184.

Daszak, P., A. A. Cunningham, and A. D. Hyatt. 2000. Emerging infectious diseases of wildlife-Threats to biodiversity and human health. Science 287: 443-449.

Epstein, P. R., E. Chivian, AND K. Frith. 2003. Emerging diseases threaten conservation. Environmental Health Perspectives 111: 506-507.

FAYER, R. 2000. Global change and emerging infectious diseases. Journal of Parasitology 86: 1174-1181.

Folinsbee, K. E., D. C. Evans, J. Fröbisch, L. A. Tsuji, and D. R. BROOKs. 2005. Quantitative approaches to phylogenetics. In Handbook of palaeoanthropology. Vol. 1: Principles, methods, and approaches, W. Henke, H. Rothe, and I. Tattersall (eds.). Springer Verlag, New York, New York. (In press.)

Global Taxonomy Initiative. 1999. Using systematic inventories to meet country and regional needs. A Report of the DIVERSITAS/ Systematics Agenda 2000 International Workshop, 17-19 September 1998, American Museum of Natural History. Center for Biodiversity and Conservation, American Museum of Natural History, New York, New York, 34 p.

Harvell, C. D., C. E. Mitchell, J. R. Ward, S. Altizer, A. P. Dobson, R. S. OstFeld, AND M. D. SAMUel. 2002. Ecology-Climate warming and disease risks for terrestrial and marine biota. Science 296: 2158-2162.

Hebert, P. D. N., A. Cywinska, S. L. Ball, AND J. R. De WaARd. 2003. Biological identifications through DNA barcodes. Proceedings of the Royal Society of London, Series B 270: 313-321.

HOBERG, E. P. 1997. Parasite biodiversity and emerging pathogens: A role for systematics in limiting impacts on genetic resources. In Global genetic resources: Access, ownership and intellectual property rights, K. E. Hoagland and A. Y. Rossman (eds.). Association of Systematics Collections, Washington, D.C., p. 71-83.

, A. Abrams, R. Carreno, and J. R. Lichtenfels. 2002. Ashworthius patriciapilittae $\mathrm{n}$. sp. (Trichostrongyloidea: Haemonchinae), an abomasal nematode in Odocoileus virginianus from Costa Rica, and a first record for the genus in the western hemisphere. Journal of Parasitology 88: 1187-1199.

, N. L. Alkire, A. DE Quieroz, ANd A. Jones. 2001. Out of Africa: Origins of the Taenia tapeworms in humans. Proceedings of the Royal Society, London, Series B 268: 781-787.

, A. Jones, R. L. Rausch, K. S. Eom, and S. L. Gardner. 2000. A phylogenetic hypothesis for species of the genus Taenia (Eucestoda: Taeniidae). Journal of Parasitology 86: 89-98.

$\longrightarrow$, A. A. KoCAN, AND L. G. RICKARD. 2001. Gastrointestinal strongyles in wild ruminants from North America. In Parasitic diseases of wild mammals, W. Samuel, M. Pybus and A. A. Kocan (eds.). Iowa State University Press, Ames, Iowa, p. 193-227.

, AND J. R. Lichtenfels. 1994. Phylogenetic systematic analysis of the Trichostrongylidae (Nematoda) with an initial assessment of coevolution and biogeography. Journal of Parasitology 80: 976996

, S. LLOYD, AND H. OMAR. 1995. Libyostrongylus dentatus n. sp. (Nematoda: Trichostrongylidae) from ostriches in North America, with comments on the genera Libyostrongylus and Paralibyostrongylus. Journal of Parasitology 81: 85-93.

, K. Monsen, S. J. KUTZ, AND M. BLouin. 1999. Structure, biodiversity and historical biogeography of nematode faunas in Hol- 
arctic ruminants: Morphological and molecular diagnoses for $\mathbf{T e}$ ladorsagia boreoarcticus $\mathrm{n}$. $\mathrm{sp}$. (Nematoda: Ostertagiinae), a dimorphic cryptic species in muskoxen (Ovibos moschatus). Journal of Parasitology 85: 910-934.

HoRwITZ, P., AND B. A. WILCOX. 2005. Parasites, ecosystems and sustainability: An ecological and complex systems perspective. International Journal for Parasitology 35: 725-732.

JANZEN, D. H. 1985. On ecological fitting. Oikos 45: 308-310.

1993. Taxonomy: Universal and essential infrastructure for development and management of tropical wildland biodiversity. In Proceedings of the Norway/UNEP expert conference on biodiversity, Trondheim, Norway, O. T. Sandlund and P. J. Schei (eds.). NINA, Trondheim, Norway, p. 100-113.

, AND W. HallwaChS. 1994. All Taxa Biodiversity Inventory (ATBI) of Terrestrial Systems. A generic protocol for preparing wildland biodiversity for non-damaging use. Report of a National Science Foundation Workshop, 16-18 April 1993, Philadelphia, Pennsylvania, $132 \mathrm{p}$.

,-- J. JiMENEZ, AND R. GÁmEZ. 1993. The role of the parataxonomists, inventory managers and taxonomists in Costa Rica's national biodiversity inventory. In Biodiversity prospecting, W. V. Reid et al. (eds.). World Resources Institute, Washington, D.C., p 223-254.

KENNEDY, C. R. 1993. Introductions, spread and colonization of new localities by fish helminth and crustacean parasites in the British Isles: A perspective and appraisal. Journal of Fish Biology 43: 287301.

Kutz, S. J., E. P. Hoberg, J. Nagy, L. Polley, and B. Elkin. 2004.
Emerging parasitic infections in Arctic ungulates. Integrative and Comparative Biology 44: 109-118.

LANKESTER, M. W., AND D. FONG. 1989. Distribution of elaphostrongyline nematodes (Metastrongyloidea: Protostrongylidae) in Cervidae and possible effects of moving Rangifer spp. into and within North America. Alces 25: 133-145.

Samuel, W. M., M. J. Pybus, D. A. Welch, and C. J. Wilke. 1992. Elk as a potential host for meningeal worm: Implications for translocation. Journal of Wildlife Management 56: 629-639.

Scholz, T., AND H. CAPPELLARO. 1993. The first record of Corallobothrium parafimbiratum Befus et Freeman, 1973 (Cestoda: Proteocephalidea), a parasite of North American catfishes (Ictalurus spp.), in Europe. Folia Parasitologica 40: 105-108.

Torchin, M. E., K. D. Lafferty, A. P. Dobson, V. J. McKenzie, and A. M. KURIS. 2003. Introduced species and their missing parasites. Nature 421: 628-629.

WoJCICKI, M., AND D. R. BROOKs. 2004. Escaping the matrix: A simple and powerful algorithm for comparative phylogenetic studies in coevolution. Cladistics 20: 341-361.

, AND 2005. PACT: A simple and powerful algorithm for deriving general area cladograms. Journal of Biogeography 32: 755-774.

WOODFORD, M. H., AND P. B. Rossiter. 1994. Disease risks associated with wildlife translocation projects. In Creative conservation: Interactive management of wild and captive animals, P. J. S. Olney, G. M. Mace, and A. T. C. Feistner (eds.). Chapman \& Hall, London, U.K., p. 178-220.

Woolhouse, M. E. J. 2002. Population biology of emerging and reemerging pathogens. Trends in Microbiology 10(suppl.): S3-S7.

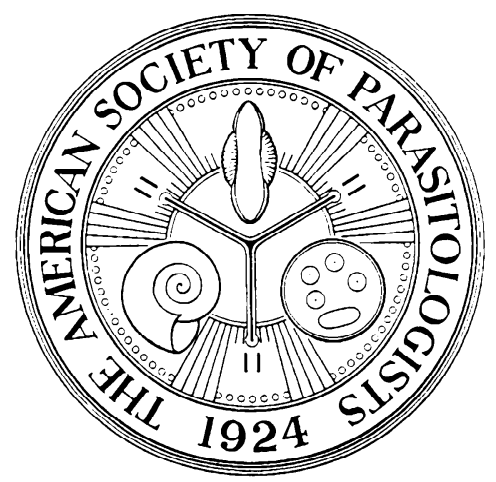

Date of Publication

Volume 92, No. 2, was mailed 28 April 2006 